included in the annual volume must be reduced, and thus the issne of the monographs delayed. This announcement is not altogether creditable to the geologists of Great Britain. The number of persons interested in the study of this science has not diminished, nay, has become decidedly larger, since the foundation of the Palæontographical Society. Many more than those whose names are on the list of subscribers could well spare the annual guinea needed to secure the efficiency of the work, but it may be feared that there is among them some lack of public spirit. The rapid development of every branch of geology has perhaps contributed to this by rendering its students more of specialists than they formerly were; but even if the number of monographs in the series bearing on this or that man's hobby be small, he is bound, I think, on public grounds to see that this useful work does not languish for want of funds. In almost every career of life there are certain associations to which one feels bound to belong: may I then be forgiven for suggesting that every geologist not absolutely impecunious sbould consider the Palæontographical Society one of these. True, the number of back volumes is now formidable to those who desire a complete set, but these can be purchased on easier terms by subscribers, and the less wealthy student may console himself for a broken series by the thought that he is doing a good work in securing its continuance.

T. G. BonNeY.

NOTES ON PHENACODUS.

Sir,-I must remark on your late article on Phenacodus ' (GeoLogical Magazine, No. 260), that having selected for publication my earliest conclusions regarding it, issued in 1881 , my more mature views are not stated. In order to insure the dissemination of the latter rather than the former, through your journal, I give the following points.

A few months after the publication of the note from which you have principally copied, I published a systematic analysis of the Ungulata in the Proceedings of the American Philosophical Society (1882). in which it was shown that the carpal bones in Phenacodus are in linear and not alternating series, and that it therefore cannot be referred to the Perissodactyla. With the Hyracoidea and other forms having similar carpal and tarsal characters it was placed in an order Taxeopoda. This order I regarded and still regard as ancestral to all Ungulata, Amblypoda and Proboscidea included. It thus realized, so far, the prophecy which I made in 1874 (Journal Academy Philad.), that the ancestral type of higher Mammalia would prove to be pentadactyle and bunodont. The history of this question is set forth in my illustrated account of the Condylarthra published in the "American Naturalist" for 1884.

A further study of the extinct Taxeopoda has shown me that although furnished with hoof-like unequal phalanges, they are not very different from the Lemurs of the primitive type known as the Adapidæ. I now believe that the order Taxeopoda must include

1 See February No. pp. 49-52, Pl. II. 
not only Phenacodus and allies (=Condylarthra), but also Hyracoidea, Lemuroidea, Simmopithecoidea, and Anthropoidea, although the last-named diverge a little in the characters of the carpus. Moreover, some of the Taxeopoda of the Puerco epoch show that the Unguiculate forms can readily have descended from them, for as the carpus and tarsus of this order are thoroughly Unguiculate, it only requires intermediate forms of ungues to connect tbem, and these have been found. These facts and conclusions are set forth in the "American Naturalist" for 1885, in a paper on the "Evolution of the Vertebrata Progressive and Retrogressive."

It thus appears that Lemurine forms were the ancestors of all Placental Mammalia, as was already anticipated by Haeckel in his far-seeing " Schöpfungsgeschichte."

E. D. Copr.

\section{NOTE ON ERISICHTHE.}

SIR,-A careful perusal of Mr. Davies' note on this subject in your number for March reveals the fact that he agrees with me in the association of the fin-spines in question with Erisichthe, and not with Ptychodus. He corrects me as to the authorship of the term Xiphias Dixoni, and agrees with me again that the weapon of that species also belongs to the fish I have called Erisichthe. But he wishes me to use the name Protosphyrana, Leidy, in the place of the one I have proposed. In this point I hope Mr. Davies will yet again agree with me.

Two species are catalogued ${ }^{1}$ by Leidy under the name of Protosphyrana, $P$. ferox and $P$. striata. If now his $P$. ferox be a species of the genus I have named Erisichthe, Leidy's name should, in accordance with all usage, be retained for the $P$. striata, provided the two belong to different genera. When in London, in 1878, either Mr. Davies or Mr. E. T. Newton showed me a jaw containing teeth of the $P$. striata, which was plainly not an Erisichthe. For this statement I depend on memory alone. If I be correct, it is for this genus that the name Protosphyrena should be retained, if it be used at all.

In its present status, however, the name in question is nomen $n u d u m$, and under the rules not more entitled to recognition than new names in museum or sale catalogues. The rules of the American and British Associations are explicit on this point, and properly so.

E. D. Copr.

\section{NOTOCHELYS COSTATA, OWEN.}

Sir,-In his description of this interesting fossil, ${ }^{2}$ Sir Richard Owen stated that the "nature and age of the deposit from which it came was unknown to him." I am informed by Prof. Archibald Liversidge, by whom Notochelys was sent to Prof. Owen, that it was found associated with certain other fossils described ${ }^{3}$ by myself from

1 The name is not referred to in the text of his paper by Leidy, but only appears in a catalogue at the end of it.

2 Quart. Journ. Geol. Soc. 1882, vol. xxxviii. p. 178.

3 Journ. R. Soc. New South Wales for 1883 [1884], vol. xvii. p. 87. 